\title{
MESTRES E DISCIPULOS
}

Damos, linhas abaixo, a magnifica licção inaugural com que o nosso Director, o Prof. Rubião Meira, abriu o curso de clinica medica (1. ${ }^{\text {a }}$ cadeira) aos seus alumnos de 1923. Estamos convencidos que só proveito trará aos estudantes a leitura de peças como esta, onde tão bem se dizem verdades tão dignas de se considerarem e praticarem.

\section{LICÇÃO INAUGURAL}

PELO DR. RUBIÃo MEIRA

Meus senhores.

Nesta primeira licção estabelece a praxe que ao nos encontrarmos pela primeira vez nos apresentemos uns aos outros. Mas. eu já sou vosso conhecido, sinão de todos, ao menos da maior parte, mas quero crer que o seja de todos. Porque, eu sou conhecido como verdadeiro amigo da mocidade, como seu constante defensor, como propugnador das idéas liberaes, como amante das forças vivas da nação, que são a juventude illustrada desta nossa cara terra. E eu vos conheço porque vós todos são iguaes - é a eterna gente que enche os bancos academicos, sempre a mesma gente, cheia de aspirações, com o coração a transbordar de esperanças, a alma exhuberante de fé, coragem nas acções, independencia de caracter - condições estas que só residem naquelles çue inda não se macularam no trafego da vida. Vindes com a alegria dos verdes annos, que ainda não tropeçaram nas mazelas do mundo. Tendes ainda a alvura da innocencia, porejando pelos vossos gestos, vivendo em vossas palavras. Reunis tudo o que é nobre e tudo o que é brando. E' por isso que eu amo a mocidade, $\dot{c}$ por isso que eu me sinto bem ao contacto do calor juvenil. Daesme a força para as luctas, em que vou despendendo as minhas derradeiras energias, encoraja-me sempre a visão dessa juventude amada quando entro nas pelejas, em prol do seu porvir. Somos 
portanto, bem conhecidos e as apresentações săo simples e estão feitas. Dou-vos, entretanto, com carinho as vôas vindas. Chegastes ao vosso destino. Preparado o vosso espirito com as materias cursadas até agora, vindes ler o livro que não deixareis mais d'ora avante. Digo assim em these e com animo generalisador. E' curial que realmente a maioria de meus alumnos vá ser medico na extensão da palavra, quer dizer, vá se sacrificar na vida, vestir as roupagens do maximo sacrificio, trocar as, alegrias da existencia pela tortura constante de preoccupações, do abandono do seu eu, do desvelo pelos que soffrem. E' a esses que eu falo, é a elles que me dirijo, é ans que não temem a desgraça e entram no rol dos abnegados. Eu não posso dar-vos, nesta hora, conselho algum, porque já é tarde, já tendes caminhado um pouco longe, mas si pudesse dal-o, dir-vos-ia que escolhestes mal o objectivo de vossa vida. Não encontrareis daqui por deante mais socego em vossós dias. Agora começa a verdadeira lucta em vossa intelligencia. Ides presencear o soffrimento humano estampado nas figuras dos doentes pobres. E' o soffrimento da materia alliado ao do espirito. Daqui para sempre é o que ides encontrar - a miseria da vida em toda a sua exteriorisação; e seja rico ou miseravel o doente é um coitado! Pouco the valerá a pompa da riqueza si um cancer the róe o estomago; tem que passar pela tortura da dôr, pela desgraça dos vomitos constantes e quantas vezes mesmo pela afflicção da fome! Póde ter os celeiros abarrotados, a adega prenhe de capitosos vinhos, que o seu fim está marcado, entre as agruras do desespero, si é pobre. não falemos delles meus amigos, por que esta é a casa dos desamparados, e é a caridade quem põe em vossas mãos o seu destino e o seu termo final.

Coitados dos que soffrem, deve ser daqui para deante a bandeira a fluctuar em vosso espirito. Não negueis vossos serviços cos padecentes, porque é muito triste e muito doloroso o soffrimento. Não é uma banalidade que vos digo; é um pedido que vos f́aço.

Os vossos livros ahi estão. Guardae em vossa intelligencia c glit aprenderdes agora que nunca mais vos esquecereis desses doentes. Eu nunca me olvidei dos primeiros doentes que vi. Recordo-me ainda daquella vez em que fui assistir á inicial aula do Frof. Francisco de Castro. Era um individuo portador de esplenomegalia palustre. O Mestre discorreu uma hora sobre o assumpto e eu nunca me esqueci o que naquelle dia aprendi como inda tenho fixa na retina do meu entendimento a figura amarella, apatica, o ventre abaulado, a face de desanimo daquelle infeliz. Não me esqueceram tambem os outros doentes que então examinei e sob que ouvi discorrer o Professor, que nós, com o enthısiasmo juvenil a palpitar em nosso coração, cognominavamos de 
"Divino Mestre", tal a impressão que nos causava o seu erudito ensino.

A medicina, a muitos, parece cousa facil. Pois eu vos affirmo que nada sei e que tenho visto bastante e estudado não pouco:

Vou dizer-vos uma verdade que talvez vos desencoraje, mas creio que é certo o que vos vou dizer. Não vos assusteis, entretantc, nem me cognomineis de "pessimista"

O Prof. Francisco de Castro acreditava que o medico cujo espirito é forrado de erudição e vive com os livros, erra $20 \%$ dos casos o seu diagnostico. Causou assombro essa affirmação. Era lá possivel. isto? Então a medicina é tão difficil assim? Pois, naquelle tempo, (1897) a arte diagnostica não tinha os elementos de que dispomos hoje. Eram pouzos e insignificantes. O que valiam eram só a percussão e a ascultação e pouca cousa mais. Hoje tẹmos além disso, o laboratorio, que é rico arsenal, os raios $\mathrm{X}$, a bacteriologia, a hematologia, apparelhos variados, os electrocardiographos, as inscripções vasculares, mil cousas novas e bonitas e eu acho que se erra bastante vezes e muito mais. Talvez se acerte só em $\left.20^{\circ}\right|^{\circ}$ dos casos. Nos 80 restantes ou claudica o diagnostico, ou fálha o prognostico ou fallece a therapeutica - e quem paga com isso é o doente, que se vae embrulhado. E' que eu tenho a coragem de vos dizer o que muitos sentem e não podem, por isto ou por aquillo, fazer o mesmo.

$\mathrm{H}$ dias eu e um velho amigo, medico de competencia avantajada, acompanhavamos o feretro de um outro bonissimo amigo, que findara mais ou menos obscuramente. Era no Cemiterio do Araçá que seus despojos iam repousar. Deante da parte nova daquelle campo santo, em que as cruzes assignalam os corpos defuntos, multidão infinda de cruzes a attestar a immensa gente a.li a descançar no socego eterno, diz-me o meu collega, com seu espirito observador e sua finura de espirito: " $E$ ' muito individuo aqui enterrado. Dize-me uma cousa, a tua opinião sincera. Não achas que a maior parte para aqui não veio por erro nosso, ou nos diagnosticos ou na therapeutica? Não crês que muitos desses que ahi estão foram para aqui mandados antes do tempo?" Ao que eu the retruquei inteiramente de accordo com o seu pensar e creio firmente que nós temos uma pouquinha de culpa no enchimento dos cemiterios.

Agora, quando digo nós, digo mal talvez. Porque não somos nós, é a medicina, é a nossa sciencia que realmente é muito cheia de difficuldades. Imaginem os meus caros alumnos que isto é assim para os que estudaram e estudam e vejam agora o que não será para os que passam os annos escolares na galhofa e os annos de tirocinio nos recreios do espirito. E' por isso que eu vos aconselho a observar o doente, pois o seu exame aprofundado vale mais 
que todos os raios $\mathrm{X}$ do mundo e todos os apetrechos do universo. Sem a primeira parte do exame - o mais de nada vale. Que importa ao medico conhezer o superfluo da medicina que é o abuso dos apparelhos, o uso dos laboratorios si elle não atinou ainda com o crgão lesádo? Si a medicina só valesse por isso seria muito facil. Eu vou demonstrar o que affirmo. Si a clinica fosse feita só com o emprego dos meios extranhos á anamnese e ao exame objectivo do doente não seria mais que o resultado de uma formula algebrica de $\mathrm{a}+\mathrm{b}=\mathrm{c}$.

$\mathrm{O}$ doente tem febre. Faz-se o exame do sangue e procurase o hematozoario, faz-se o Widal e a hemocultura. Contam-se os globulos brancos na totalídade e na sua especificação. Tira-se a radiographia do thorax e do abdomen. Faz-se a pucção lombar e examina-se o liquido cephalo-rachidiano. Examinam-se as urinas; faz-se a cryoscopia. Dósa-se a urea do sangue. Examinam-se os seus esputos e as suas fezes. Tudo isso veio negativo. O doente nada deve ter. A febre tem que ser nervosa. Não é um doente que shi está, mas sim um nevropatha. Mas, um bello dia os phenomenos se incrementam, a febre sóbe, perturbações graves apparecen: e o doente morre. De que? De nevropathia? Não. De febre? Talvez. Mas o facto é que o doente se vae desta para melhor ou peior e $D$ medico ficará a ver navios. Digo fi:ará porque o verdadeiro clinice liga a esse enxame de exames a importancia relativa que elles merecem e excluidas as principaes hypotheses que o preoccuparam ao mandar pratical-os, conclue de geito differente, abandoiando essa superfluidade toda que é destituida de valor. A in¿’agação de como começou a pyrexia, das condigões outras. que cercam o caso, dos demais phenomenos morbidos que acompanham a elevação thermica, pode levar o diagnostico na ausencia de positividade dessas pesquizas de laboratorio.

$\mathrm{E}$ ' certo que os demais meios diagnosticos afóra o exame objectivo do doente, não devem e não podem ser despręzados. Mas, fiar delles o juizo clinico é erro sobre que não cesso de falar, é erro sobre que bato sempre, é erro em que não devem incidir os que me ouvem. Fiar-se nos raios $\mathrm{X}$ para formar o diagnostico é um absurdo. Affirmo isso sem receio de contestação. Conheco muitos casos em que si o medico fosse seguir só o conselho dos raios $\mathrm{X}$ teria feito triste figura. Innumeros poderia contar-vos. Quantas vezes o radiographista - pobre illusionista - assegura que não ha tal cousa e a tal cousa existe. A mim, uma vez, deante de um doente de cancer do estomago, clinicamente diagnosticavel, por todos os elementos em scena, e em quem havia formulado a opinião, veio o resultado da radiographia - que o padecente nada tiriha no estomago; o mal estava no figado, não havia cancer. Mas, a familia, apertada entre os dois diagnosticos e naturalmen- 
te se inclinando para o lado de maior benignidade, fez questão da intervenção, que revelou um cancer occupando o estomago e impossivel de ser enucleado.

Como esse facto poderia citar-vos outros, mas não é necessario para dar-vos uma idéa, que é a que tenho, de que os raios $\mathrm{X}$ servem muito para a confirmação do juizo, mas não bastam e a meu ver, não tem poder para infirmar um diagnostico feito. Inda ha dias, consultado por um doente, em que a radiographia havia affirmado a existencia de cavernas no pulmão, assegurei-lhe, com a minha responsabilidade, que queimasse a photographia e tocasse o barco. E para vos demonstrar a veracidade da minha opiniâo, basta dizer-vos uma cousa, que vós intelligentes, comprehendereis o alcance Para patentear que o erro tambem existe ahi e quantos erros, Santo Deus - basta que saibaes que si fizerdes a radiographia de um doente em varios radiographadores, ella In nca concorda. Um dir-vos-a que existe dilatação da aorta, outro que ha apenas dilatação do coração e outro que nada ha. E,' um facto esse que qualquer clinico póde perfeitamente delle se inteirar Isto basta para tirar-lhe o valor - que só existe no espirito de gente leiga. Porque, si a medicina se circumscrevesse ao resultado da applicação desse exame seria muito mais logico que ao envez de perderdes 6 annos aqui a nos ouvir tagarellar. montasseis um laboratorio de raios $\mathrm{X}$ e começasseis a ver as entranhas de todo o mundo. Seria mais commodo, embora mais dispendioso, mas seriam mais seguros os resultados. Não, meus caros amigos, a medicina não é isto. Deixae-me bater ainda mais um puco nessa tecla, para que possa eu chegar á conclusão do que vos quero dizer. Não confieis demasiado nos exames de laboratorio. Conto-vos por alto um caso. Doente com febre, vindo de zona desconhecida. Typo febril continuo, perturbações geraes sem valor; arrepios de frio ligeiros, pela manhã. Imposibilidade de formar desde logo o diagnostico. Suspeita-se o implaudismo. A medicação não dá resultado. Vae-se ao typho; as pesquizas todas absolutamente negativas. E, a febre continua; apparecem vomitos, tosse com esputos sanguineos, phenomenos nerivosos e cardiacos. Falta-me dizer que a pesquiza do hematozoario é tambem negativa, embora repetidas vezes praticada. Emmagrecimento progressivo, anemia accentuada vem apparecendo e a febre sempre ali, do mesmo modo, zombando da medicação, zombando da therapeutica mais radical possivel. Renovam-se os exames; procura-se o hematozoario novamente e o foi por 4 vezes, applica-se o quinino e o azul de methyleno e nada. O que pensar disso? O laboratorio dançou. Tudo o que se póde procurar se procurou e nada se achou. 
Mas, a opinião do implaudismo bailava no espirito do clinico. Pela 5. ${ }^{a}$ vez faz colher o sangue e passados dous mezes que durava aquella scena morbida, já cançados, o doente, os enfermeiros, os medicos e os analystas, ahi wem o resultado - presença de hematozoarios!

Quer dizer que si o medico não tivesse amparado o organismo e cercado a resistencia do individuo de elementos capazes de supportar a molestia, si não duvidasse sempre dos exames e os. fizesse repetir, jamais chegaria a formar uma opinião e o doente desceria á cova. sem diagnostico, ou com diagnostico errado.

Ahi está um facto entre muitos outros que eu vos poderia citar e que o não faço para não vos fatigar.

Eu creio, por isso, e é ao que eu quero chegar, que si hoje se erra mais é porque o espirito clinico está desapparecendo da cabeça dos medicos. Deante de cada caso mais embrulhado o clinico grita logo pelo auxilio do laboratorio, comprehendendo nessa palavra, os demais meios propedeuticos afóra o exame obejectivo. thi está a causa do maior numero de erros. E, com uma pesquiza falsa, tudo mais será falso e quando o clinico acorda e dá um ponta-pé nessas cousas é tarde e perdeu-se muito tempo. Tratae, portanto de educar a vossa intelligencia na observação cuidadosa dos doentes; procurae fixar os symptomas apresentados pelo doente e comparae-os com os que os tratadistas assignalam para dadas molestias, fazei rapidamente em vossa mente um trabalho de analyse e em seguida um outro de synthese que assim podereis chegar a uma conclusão que não esteja muito longe da verdade. Aprendei a examinar bem o doente, dos pés á cabeça, sem deixar um só orgão, um só apparelho de lado. Fazei uma anamnese rigorosa, porque deveis saber que muitas molestias existem em que só ella vale muito mais do que todo o resto. Assim para as affecções gastricas, assim para as molestias mentaes.

Não desprezeis um facto, porque por mais miudo que seja póde elucidar o vosso juizo. Tudo serve e tende paciencia com a historia que o doente vos vae contar. Um accidente antigo póde immediatamente esclarecer aquillo que procuraes. Uma vez estabeleci o diagnostico de ulcera do duodeno só porque a doente me narrou no meio de mil cousas sem valor e de circumstancias, sem precisão, que havia tido uma enterorrhagia. Talvez a outros co!legas não houvesse dito isto ou porque the escapasse ou porque não tivessem tido paciencia de ouvir tudo. Foi talvez por este motivo que o diagnostico a outros escapou e eu o firmei vendo-o coniirmado pelo acto operatorio. Nada deveis perder do que vos diz o doente. Tudo serve e tudo tem valor. E, mais importancia tem, é credo meu, a anamnese bem feita, cuidadosamente praticada, que o auxilio dos outros meios propedeuticos. 
Tratae, vós que sois moços, de educar o sentimento clinico. Muitos o tem de nascença, nascem medicos, como poderiam nascer musicos, mas outros formam a intuição clinica, como um outro que aprende a arte e a diagnifica e a illustra.

E' a observação que deve ser a base sobre que haveis de constituir o vosso edificio futuro. E, aqui tendes, deante de vós, o manancial fecundo que ha de vos abarrotar de ensinamentos e que é o hospital. Aqui forrareis o vosso espirito dos sentimentos grandes que vos farão gente na extensão da palavra.

Não deixareis de aqui vir beber as licções que vos são necessarias. Eu aqui fico, como mais velho, para iniciar-vos com cs votos para que ao sahirdes daqui conserveis a certeza de não haver perdido o vosso tempo.

Tal é o meu maior desejo, nem outro tão grande posso ter.

\section{Rubião Meira.}

(1) Esta liç̧ão fel-a o Prof. Rubião publicar ta:mbem na "Gazeta Clinica", onde sahiu no n.v 2 deste anno:

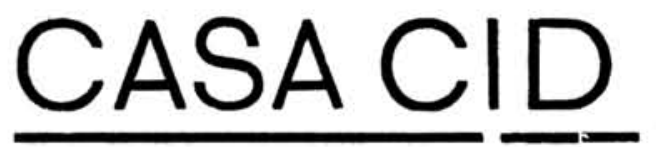

ARTIGOS PARA LABORATORIOS DE BACTERIOLOGIA, ANALYSES, HYPODERMIA.

$\neg$ REAGENTES E CORANTES -

Medicina, Cirurgia, Physica, Chimica e Historia Natural

WALKYRIA, o melhor esmalte para unhas (resistente á lavagem)

\section{PLINIO COSTA\& COMPANHIA}

Importadores de Artigos Scientificos

Perfumarias finas - Electri- Ampoulas - Officinas de Nicidade - Optica e Cuteiaria ckelagem e Reparações. - -

Telephone: Central, 5468 - Telegramma: CID

CODIGOS: Ribeiro e A. B. C. 5." Edição

RUA DE S. BENTO N. 41 - S. PAULO

Depositarios dos productos do Laboratorio Pasteur, da Bahia 